\title{
Review
}

Neonatology

Neonatology 2016;110:155-162

DOI: $10.1159 / 000444918$
Received: November 16, 2015

Accepted after revision: February 23, 2016

Published online: April 23, 2016

\section{Ventilation-Induced Brain Injury in Preterm Neonates: A Review of Potential Therapies}

\author{
Samantha K. Barton ${ }^{a}$ Mary Tolcos ${ }^{a-c}$ Suzanne L. Miller ${ }^{a, b}$ \\ Charles Christoph Roehr ${ }^{a, d}$ Georg M. Schmölzere,f Timothy J.M. Moss ${ }^{a, b}$ \\ Stuart B. Hooper ${ }^{a, b}$ Euan M. Wallace ${ }^{a, b} \quad$ Graeme R. Polglase ${ }^{a, b}$ \\ ${ }^{a}$ The Ritchie Centre, Hudson Institute of Medical Research, and ${ }^{b}$ Department of Obstetrics and Gynecology, Monash \\ University, Clayton, Vic., and 'School of Health and Biomedical Sciences, RMIT University, Bundoora, Vic., Australia;

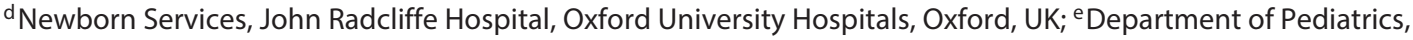 \\ University of Alberta, and ${ }^{f}$ Centre for the Study of Asphyxia and Resuscitation, Neonatal Research Unit, Royal \\ Alexandra Hospital, Alberta Health Services, Edmonton, Alta., Canada
}

\section{Key Words}

Ventilation · Neonate · Delivery room · Brain · Resuscitation · Therapy

\section{Abstract \\ Mechanical ventilation is a risk factor for cerebral inflamma- tion and brain injury in preterm neonates. The risk increases proportionally with the intensity of treatment. Recent stud- ies have shown that cerebral inflammation and injury can be initiated in the delivery room. At present, initiation of inter- mittent positive pressure ventilation (IPPV) in the delivery room is one of the least controlled interventions a preterm infant will likely face. Varying pressures and volumes admin- istered shortly after birth are sufficient to trigger pathways of ventilation-induced lung and brain injury. The pathways involved in ventilation-induced brain injury include a com- plex inflammatory cascade and haemodynamic instability, both of which have an impact on the brain. However, regard- less of the strategy employed to deliver IPPV, any ventilation has the potential to have an impact on the immature brain. This is particularly important given that preterm infants are}

\section{KARGER}

E-Mail karger@karger.com

www.karger.com/neo already at a high risk for brain injury simply due to immaturity. This highlights the importance of improving the initial respiratory support in the delivery room. We review the mechanisms of ventilation-induced brain injury and discuss the need for, and the most likely, current therapeutic agents to protect the preterm brain. These include therapies already employed clinically, such as maternal glucocorticoid therapy and allopurinol, as well as other agents, such as erythropoietin, human amnion epithelial cells and melatonin, already showing promise in preclinical studies. Their mechanisms of action are discussed, highlighting their potential for use immediately after birth.

(c) 2016 S. Karger AG, Basel

\section{Preterm Birth, Brain Injury and Ventilation Requirement}

Preterm birth, defined as birth prior to 37 completed weeks of gestation and with an incidence of $7-12 \%$ worldwide [1], results in the birth of neonates with underdeveloped lungs. As a result, $92 \%$ of extremely preterm infants
(C) 2016 S. Karger AG, Basel

1661-7800/16/1102-0155\$39.50/0
Dr. Graeme R. Polglase

The Ritchie Centre, Hudson Institute of Medical Research

27-31 Wright Street

Clayton, VIC 3168 (Australia)

E-Mail graeme.polglase@ hudson.org.au 
(born at $<28$ weeks of gestation) in Australia and New Zealand require some form of assisted ventilation for at least $4 \mathrm{~h}$ after birth [2]; for many, this ventilation can occur as early as in the delivery room [3]. Whilst this respiratory assistance is essential for survival, ventilation can increase the risk and incidence of brain injury. Given that extremely preterm infants are already at an elevated risk for brain injury, any intervention applied perinatally, including the initiation of respiratory support, needs to be optimized.

Unlike for the neonatal intensive care unit (NICU), there is a lack of guidelines and protocols to inform the initiation of ventilation in the delivery room and often an absence of sophisticated devices [4,5]. As a consequence, more than $85 \%$ of preterm infants who receive assisted ventilation in the delivery room are given dangerously high tidal volumes $\left(\mathrm{V}_{\mathrm{T}}\right)$ [6], with potential detrimental effects on the lungs $[7,8]$ and brain $[9,10]$. A small study of preterm infants showed an increased incidence of intraventricular haemorrhage (IVH) in babies receiving a high $\mathrm{V}_{\mathrm{T}}$ compared to babies receiving a low $\mathrm{V}_{\mathrm{T}}$ in the delivery room [11]. Thus, whilst it is well established that prolonged mechanical ventilation can be injurious to the preterm lungs and brain, ventilation-induced injury may occur as early as the initiation of ventilation in the delivery room and seems to be a potentially preventable contributor to brain injury.

The use of intermittent positive pressure ventilation (IPPV) in the delivery room is decreasing as non-invasive ventilation strategies, such as continuous positive-airway pressure, are increasingly introduced. However, despite the reduction in the number of infants requiring intubation and/or IPPV, this has not translated into improved neurological outcomes [12]. Mechanisms responsible for brain injury arising from IPPV have been identified via animal experimentation and reviewed in detail previously [13], and hence this review will focus on IPPV. Mechanistic investigations of brain injury associated with noninvasive ventilation strategies are lacking, but we anticipate that the underlying causes are similar to those elicited by IPPV.

The first pathway to brain injury from ventilation is the initiation of a pulmonary inflammatory cascade [8] which migrates systemically to the brain, where it can cause a localized cerebral inflammatory response sufficient to increase markers of oxidative stress and apoptosis $[9,10,14]$. The second pathway is caused by over-distension of alveoli and compression of pulmonary capillaries, increasing pulmonary resistance and decreasing the cardiac output [15]. Coupled with immature autoregulation and a permeable blood-brain barrier, this haemodynam- ic disturbance causes variable blood flow to the brain and cerebral protein extravasation $[10,14]$. These pathways are amplified when the initiation of ventilation encompasses a high $\mathrm{V}_{\mathrm{T}}[10]$. Whilst improving ventilation strategies can minimize some aspects of ventilation-induced lung and brain injury, it is not sufficient to mitigate injury $[10,16]$. Thus, IPPV, irrespectively of the strategy, can increase brain injury and inflammation from as early as its initiation.

Similarly to ventilation, cerebral inflammation and cerebral haemodynamic instability are also two of the critical pathways involved in preterm brain injury $[17,18]$. Thus, a preterm neonate will already be vulnerable to these pathways and a subsequent intervention, such as ventilation, can exacerbate these pathways. It is imperative that we identify an adjunct therapy that has the potential to target these two critical pathways. This will ultimately reduce ventilation-induced brain injury as well as provide protection to the already vulnerable preterm brain. An ideal therapeutic would stabilize cardiopulmonary-cerebral haemodynamics during the transition at birth and mitigate the cerebral inflammatory response. Medical databases (PubMed, EMBASE and Google Scholar) were screened, and results were limited to the English language, to review the neuroprotective benefits of current clinical antenatal treatments, i.e. maternal glucocorticosteroid therapy and allopurinol (ALLO), as well as erythropoietin (Epo), human amnion epithelial cells (hAEC) and melatonin, which are showing promise in preclinical studies. We will discuss their use as treatments, either pre- or postnatally, for ventilation-induced brain injury and their known effects on the pathways involved in ventilation-induced injury, depicted in figure 1 . The articles relevant to the purpose of this review are summarized in table 1.

\section{Prenatal Therapies}

\section{Maternal Glucocorticoid Therapy}

The synthetic glucocorticoids betamethasone and dexamethasone are routinely administered to women at risk for preterm delivery to accelerate maturation of the fetal lungs, so preterm infants can better transition at birth. The introduction of antenatal corticosteroid treatment has reduced respiratory distress syndrome rates by $34 \%$ and neonatal death rates by $31 \%$ [19], making it the cornerstone of modern perinatal care.

Studies in lambs demonstrated that betamethasone or dexamethasone treatment prior to high $\mathrm{V}_{\mathrm{T}}$ ventilation is 
Table 1. Therapeutic effects of maternal glucocorticoids, ALLO, Epo, hAEC and melatonin on the preterm brain

\begin{tabular}{|c|c|c|c|c|c|}
\hline & Stabilizes haemodynamics & $\begin{array}{l}\text { Anti- } \\
\text { inflammatory }\end{array}$ & $\begin{array}{l}\text { Anti- } \\
\text { apoptotic }\end{array}$ & $\begin{array}{l}\text { Anti- } \\
\text { oxidative } \\
\text { stress }\end{array}$ & $\begin{array}{l}\text { Decreases the } \\
\text { permeability of the } \\
\text { blood-brain barrier }\end{array}$ \\
\hline Melatonin & $\begin{array}{l}\text { Can have vasoconstrictive } \\
\text { and vasodilatory effects } \\
\text { depending on the dose }\end{array}$ & $\sqrt{ }$ & $\sqrt{ }$ & $\sqrt{ }$ & $\sqrt{ }$ \\
\hline Epo & Unknown & $\sqrt{ }$ & $\sqrt{ }$ & $\sqrt{ }$ & $\sqrt{ }$ \\
\hline hAEC & Unknown & $\sqrt{ }$ & Unknown & Unknown & $\sqrt{ }$ \\
\hline
\end{tabular}

sufficient to protect against ventilator-induced lung injury; lambs had improved ventilation parameters as well as reduced lung inflammation and gross injury [20], consistent with a lower peak inflation pressure and $\mathrm{FiO}_{2}$ and a shorter duration of ventilation in human preterm neonates [21]. The effects of steroid treatment on the developing brain are less well understood, particularly after short-term ventilation. However, betamethasone (administered $24 \mathrm{~h}$ prior to birth) and dexamethasone (administered after delivery prior to ventilation onset) did not reduce ventilation-induced systemic inflammation, suggesting that steroids are unable to prevent the systemic spread of the pulmonary inflammatory response [20]. Despite this, the ability of steroids to improve ventilation parameters may assist in maintaining haemodynamic stability. Studies in sheep have shown that betamethasone treatment decreases fetal pulmonary vascular resistance and subsequently increases pulmonary blood flow, leading to an improved cardiopulmonary transition at birth in preterm lambs [22]. Other studies have found significant vasoconstriction in the near-term brain despite hypercapnia, potentially protecting against fluctuations in the cerebral blood flow [23]. Collectively, the improved transition at birth coupled with cerebral vasoconstriction may be the underlying link between maternal steroid therapy and the well-established reduced risk of IVH in preterm infants [24]. Further studies investigating the interaction between antenatal glucocorticoid treatment and postnatal interventions on the immature brain are still required.

\section{Melatonin}

Melatonin is an endogenous neurohormone that plays an essential role in providing circadian and seasonal timing cues, with high levels of synthesis at night. Melatonin has potential neuroprotective actions, which may be mediated by a number of physiological actions. Melatonin's neuroprotective capabilities are thought primarily to arise from its high effectiveness as an antioxidant both as a direct scavenger of oxygen free radicals, particularly the highly destructive hydroxyl radical $[25,26]$, and as an indirect antioxidant via stimulation of antioxidant enzymes $[25,26]$. Melatonin also demonstrates anti-inflammatory properties, reducing upregulation of pro-inflammatory cytokines by preventing the translocation of nuclear fac-

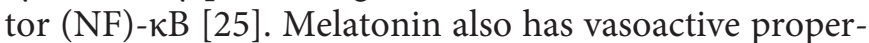
ties that may provide benefit in the perinatal period under conditions of compromise $[27,28]$. For the fetal or neonatal brain, melatonin has a number of additional important properties. It readily crosses the placenta and the blood-brain barrier and it does not have any apparent adverse effect for the mother or baby, even in high concentrations [29-31].

In light of the inflammatory and pro-oxidative stress environment that results from ventilator-induced lung injury, melatonin appears to be a compound with multiple attributes to protect the brain. In preterm infants on mechanical ventilation and with respiratory distress syndrome, postnatal treatment with melatonin reduces lung aspirate and serum concentrations of pro-inflammatory cytokines and markers of oxidative stress [32, 33]. Melatonin administration to pregnant sheep mitigates the brain production of hydroxyl radical and cellular lipid 
Fig. 1. Central pathways involved in ventilation-induced lung and brain injury. The pathways through which glucocorticoids, ALLO, Epo, hAEC and melatonin are effective are represented by the respective coloured circles. Glucocorticoids, hAEC and melatonin have the potential to prevent the amplification of injury in the lungs and the passage to the brain, whereas ALLO and Epo are more brain specific in their effects.

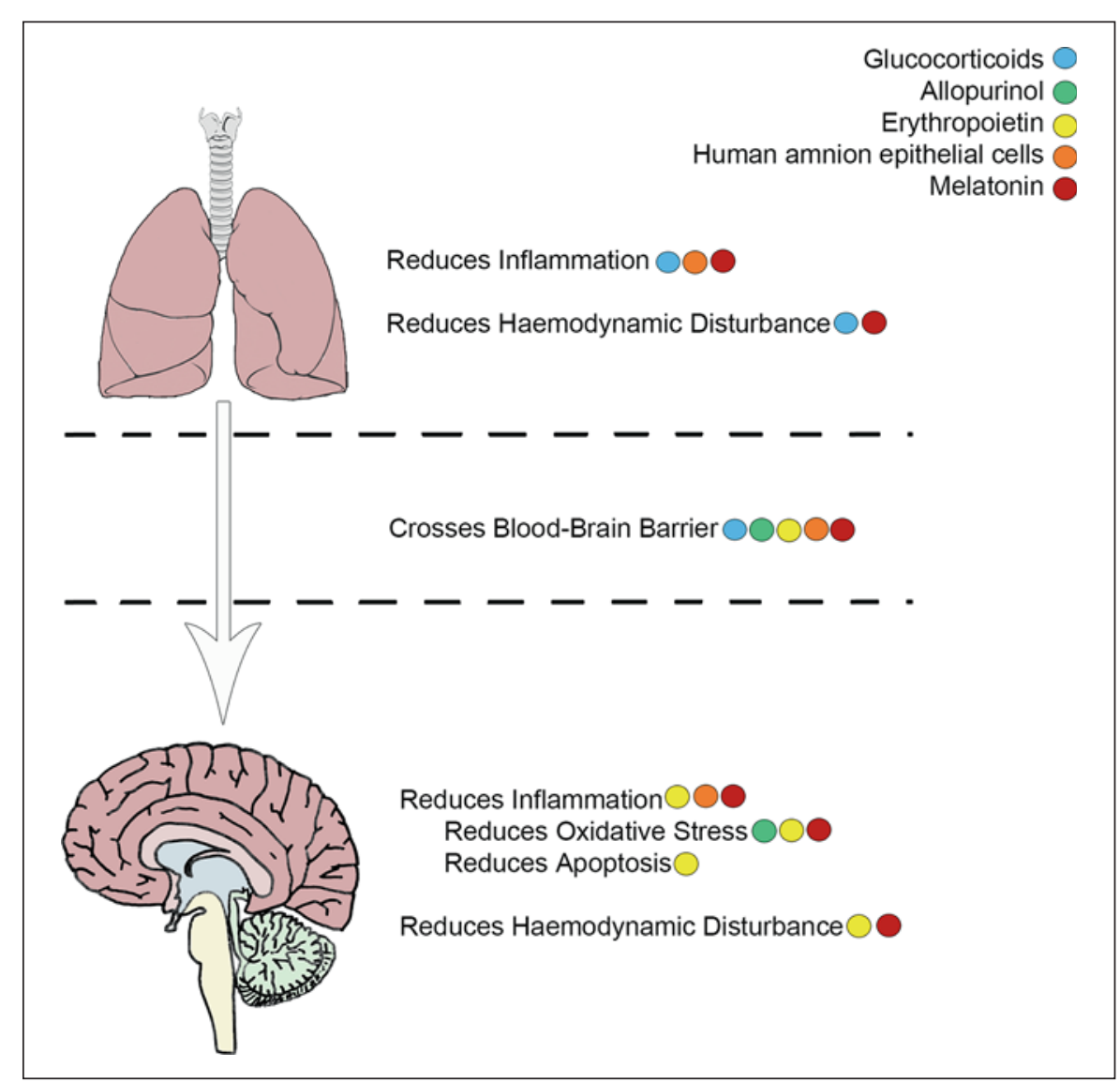

peroxidation in response to acute fetal hypoxia [31]. Antenatal melatonin decreases white-matter brain injury characterized by hypomyelination and axonal damage and improves motor and cognitive function in newborn lambs after experimental intrauterine growth restriction in sheep [29].

The effect of melatonin on ventilation-induced brain injury has not been investigated. However, prenatal melatonin administration does reduce heart and coronary vessel dysfunction in lambs exposed to chronic feto-placental hypoxia and intrauterine growth restriction [27], and postnatal melatonin protects cerebrovascular function in chronically hypoxic newborn lambs to maintain cerebral perfusion [28], suggesting that melatonin may be effective at stabilizing haemodyamics. Further, melatonin decreases brain inflammation and protects the structural integrity of the blood-brain barrier in response to acute hypoxia in fetal sheep [34]. Thus, melatonin may target both haemodynamic instability and inflammation pathways of ventilation-induced brain injury, making it an attractive adjunct therapy for future research.

\section{Postnatal Therapies}

\section{Allopurinol}

ALLO can directly, and indirectly, protect the neonatal brain from hypoxia-ischaemia. Hypoxia-ischaemia leads to hypoxanthine build-up in cells, which is metabolized to superoxide and hydroxyl radicals by xanthine oxidase; ALLO functions by inhibiting xanthine oxidase and directly scavenging free radicals [35]. Further, ALLO can convert to oxypurinol, which is capable of crossing the blood-brain barrier and also inhibiting xanthine oxidase [36].

The effects of ALLO have been investigated in term infants with hypoxic-ischemic encephalopathy. ALLO reduced $S 100 \beta$ and neuroketal, both biomarkers of brain injury [37]. Term infants who received ALLO after severe asphyxia had decreased free radical formation, improved electrical brain activity and decreased mortality [38], without longer-term increased morbidity [39]. However, a multicentre randomized placebo-controlled trial showed that maternal treatment with ALLO during fetal 
hypoxia did not reduce cord blood biomarkers of neuronal damage [40]. Further, ALLO treatment of a cohort of preterm infants with periventricular leucomalacia and retinopathy of prematurity, and elevated levels of oxidative markers, showed no clinical benefit [41].

To date, ALLO treatment at the initiation of ventilation has not been investigated. ALLO has not been effective at reducing chronic lung disease and BPD in preterm infants [42] and, since recent trials have not demonstrated a profound neuroprotective effect of ALLO in preterm infants, it might best be investigated as an adjunct therapy with improved respiratory care. There is also no clear difference between pre- and postnatal treatment, so timing of treatment also requires elucidation. Given that an ideal adjunct therapy for ventilation-induced brain injury should be administered soon after ventilation onset, we recommend investigating ALLO as an early postnatal treatment. We believe that, given that oxidative stress is a critical pathway through which ventilation can harm the lungs and brain, ALLO may provide acute protection against the activation of oxidative stress pathways.

\section{Erythropoietin}

Epo is a glycoprotein cytokine involved in erythropoiesis. It has antiapoptotic, anti-inflammatory and neuroregenerative properties and is used for treatment of adult stroke and anaemia of prematurity [43].

The efficacy of Epo as a neuroprotective agent has been extensively studied in term animal models. In rat and sheep models of perinatal brain injury, high-dose human recombinant Epo was not only safe and well tolerated but also reduced cell death, microgliosis, astrogliosis and blood-brain barrier leakage [44-46]. These findings led to the investigation and demonstration of Epo as a neuroprotective therapy in term infants with hypoxic-ischemic encephalopathy, with no adverse effects noted [47]. Lower doses of Epo administered over a longer duration from within the first $48 \mathrm{~h}$ of life to 2 weeks after birth reduced disability, and the incidence of cerebral palsy and death, in term infants with moderate hypoxic-ischemic encephalopathy [48].

Less is known about the effects of Epo in preterm infants. One clinical trial of low-dose Epo 3 times per week found a trend for improved neurological outcomes and a reduced requirement for blood transfusions [49]. In a school-age follow-up study, $9 \%$ of preterm infants who received high-dose Epo for up to weeks after birth demonstrated major neurological impairments compared to $23 \%$ of their control group. Furthermore, they found normal development and a regular school attendance in only

Potential Therapies for

Ventilation-Induced Brain Injury
$6 \%$ of their control group compared to $52 \%$ of the Epotreated group, all of whom had IVH in the early newborn period [50]. In contrast, in 142 preterm infants $(<1,250 \mathrm{~g}$ at birth) to whom Epo $(400 \mathrm{IU} / \mathrm{kg})$ was administered 3 times per week from day 4 of life for 8-10 weeks, there were no differences in most indices assessed. There was, however, an increased incidence of severe IVH in the Epo group (12.2 vs. $2 \%)$ and a significantly greater number with an abnormal psychomotor developmental index (31 vs. $13 \%$; $\mathrm{p}<0.05$ ) assessed at $18-22$ weeks' corrected age [51]. Hence, based on current data, the efficacy of Epo for preterm infants is not clear; clinical trials are continuing to clarify the outcomes of its use.

The majority of studies using Epo delay the onset of treatment. Relatively few studies have assessed the effect of Epo given hours, rather than days, after birth. One clinical trial in preterm infants with multiple high doses of Epo given as early as $3 \mathrm{~h}$ after birth found trends of increased IVH, periventricular echodensity and neonatal death [52]. In contrast, a more recent trial using the same dosing regimen found a reduction in white and grey matter loss using magnetic resonance imaging in infants treated with Epo [53]. Animal studies are now investigating whether Epo maintains its neuroprotective capacity when administered soon after birth. When a single high dose of Epo was administered to lambs receiving high $V_{T}$ ventilation, lung inflammation and injury were amplified compared to results with a high $\mathrm{V}_{\mathrm{T}}$ alone [54]. Within the brain, Epo treatment had regional effects; gene expression of pro-inflammatory cytokines was elevated in the periventricular white matter after Epo administration, but there was a reduction in the size and density of microglial aggregations, decreased astrogliosis and increased integrity of the blood-brain barrier in the subcortical white matter [14]. These findings suggest a potential toxicity of early Epo treatment in preterm ventilated newborns. We believe that it is not a good candidate for therapy at this time but certainly warrants further investigation.

\section{Human Amnion Epithelial Cells}

Cell therapies offer great promise for the prevention and treatment of tissue injury in newborns $[55,56]$. The placenta offers a rich source of therapeutic cell types, and the amnion, in particular, offers exciting possibilities for perinatal therapy. The amnion, i.e. the membrane that surrounds the developing fetus, has been used clinically for wound healing for decades $[57,58]$. Epithelial cells can be abundantly isolated from the amnion and demonstrate reparative and regenerative properties. 
Briefly, the derivation of the amnion from the epiblast occurs prior to gastrulation, resulting in amnion epithelial cells having a pluripotent capacity similar to that of embryonic stem cells $[59,60]$. This has been extensively characterized; epithelial cells derived from the amnions of term human pregnancies express molecular markers of pluripotent stem cells and can be differentiated in vitro down ectodermal, mesodermal, and endodermal lineages [59]. These findings render hAEC a realistic candidate for use as a regenerative therapeutic agent [61]. Their collection during a caesarean section from tissue otherwise discarded means they do not raise the same ethical concerns as stem cells derived from human embryos. In addition, several other attributes of hAEC make them attractive for use as a cell-based therapy: they have low immunogenicity, maintain their karyotype in culture, have long telomere lengths and a high telemorase activity and, unlike embryonic stem cells, do not form teratomas in vivo [59, $61,62]$.

hAEC have the capacity to protect and repair the neonatal lung. In fetal sheep ventilated in utero for $12 \mathrm{~h}$, $\mathrm{hAEC}$ administration reduced collagen and elastin deposition and decreased fibrosis when lungs were analysed 7 days later; hAEC had also differentiated into type I and II alveolar cells [63]. hAEC also protected the fetal lung against inflammation-induced damage; hAEC delivered in utero 0,6 and $12 \mathrm{~h}$ after intra-amniotic LPS improved the tissue-to-airspace ratio and the septal crest density, reduced inflammatory cytokines, and increased surfactant protein mRNA levels in the lungs 7 days after treatment [64]. Given the success of these experimental studies, a trial has commenced investigating the safety of intravenously administered hAEC for preterm infants at $<28$ weeks of gestation with established bronchopulmonary dysplasia at a postmenstrual age of 36 weeks (trial ID ACTRN12614000174684).

The effects of hAEC on neonatal brain injury are less explored. hAEC are able to differentiate along the ectodermal lineage and can differentiate into neuronal and glial cells [65]. They express neural genes and secrete multiple neurotransmitters $[66,67]$. Only one study to date has demonstrated neuroprotective and anti-inflammatory responses after intravenous and intratracheal hAEC administration in the neonatal brain following inflammation-induced brain injury in fetal sheep [68]. Given that hAEC are able to protect the preterm lung from in utero ventilation- and inflammation-induced lung injury $[63,64]$, and that they protect the brain from in utero inflammation-induced damage [68], they may also have the potential to protect against ventilation-induced brain injury as a postnatal treatment. We observed an apparent beneficial effect of hAEC on brain inflammation as a result of high $\mathrm{V}_{\mathrm{T}}$ ventilation; hAEC (administered both intravenously and intratracheally) reduced microgliosis and vascular protein extravasation in the brain $2 \mathrm{~h}$ after of ventilation onset [9]. However, hAEC did not stabilize the haemodynamic transition following ventilation onset, yet this pathway deserves further investigation. These initial observations suggest that cell therapies alone may not be sufficient to prevent ventilation-induced brain injury, but their anti-inflammatory and reparative characteristics may make them an effective adjunct treatment.

\section{Conclusion}

Many preterm infants will require some form of respiratory support in the delivery room, often in the form of IPPV. Both manual and mechanical ventilation in the delivery room is not well controlled and can be inadvertently injurious to the preterm lungs and brain. Even minimally invasive ventilation strategies can result in brain injury in preterm infants, so there is a critical need for therapies. The ultimate therapy would have the capacity to stabilize cardiopulmonary-cerebral haemodynamics and reduce lung, systemic and brain inflammation in order to reduce ventilation-induced lung and brain injury. We hope that with additional research the optimal therapy to minimize the burden of ventilation-induced brain injury on preterm infants will be identified.

\section{References}

1 Howson CP, Kinney MV, Lawn JE (eds): Born Too Soon: The Global Action Report on Preterm Birth. Geneva, WHO, 2012.

2 Abeywardana S: The Report of the Australian and New Zealand Neonatal Network. Sydney, ANZNN, 2006.

3 Li Z, Zeki R, Hilder L, Ea S: Australia’s Mothers and Babies. Canberra, AIHW, 2011, pp 80-82.
4 Roehr CC, Kelm M, Proquitté H, Schmalisch G: Equipment and operator training denote manual ventilation performance in neonatal resuscitation. Am J Perinatol 2010;27:753758.

5 O'Donnell CPF, Davis PG, Morley CJ: Resuscitation of premature infants: what are we doing wrong and can we do better? Neonatology 2003;84:76-82.
Barton/Tolcos/Miller/Roehr/Schmölzer/ Moss/Hooper/Wallace/Polglase 
6 Schmölzer GM, Kamlin OC, O’Donnell CPF, Dawson JA, Morley CJ, Davis PG: Assessment of tidal volume and gas leak during mask ventilation of preterm infants in the delivery room. Arch Dis Child Fetal Neonatal Ed 2010;95:F393-F397.

7 Hillman NH, Kallapur SG, Pillow JJ, Moss TJ, Polglase GR, Nitsos I, Jobe AH: Airway injury from initiating ventilation in preterm sheep. Pediatr Res 2010;67:60-65.

8 Hillman NH, Moss TJM, Kallapur SG, Bachurski C, Pillow JJ, Polglase GR, Nitsos I, Kramer BW, Jobe AH: Brief, large tidal volume ventilation initiates lung injury and a systemic response in fetal sheep. Am J Respir Crit Care Med 2007;176:575-581.

9 Barton SK, Melville JM, Tolcos M, Polglase GR, McDougall ARA, Azhan A, Crossley KJ, Jenkin G, Moss TJM: Human amnion epithelial cells modulate ventilation-induced white matter pathology in preterm lambs. Dev Neurosci 2015;37:338-348.

10 Polglase G, Miller SL, Barton SK, Baburamani AA, Wong FY, Aridas JDS, Gill AW, Moss TJ, Tolcos M, Kluckow M, Hooper SB: Initiation of resuscitation with high tidal volumes causes cerebral hemodynamic disturbance, brain inflammation and injury in preterm lambs. PLoS One 2012;7:e39535.

11 Mian Q, Cheung PY, Polglase G, O'Reilly M, Kushniruk K, Aziz K, Schmölzer GM: Does high tidal volume delivery during positive pressure ventilation at birth cause brain injury in preterm infants? Proc Pediatr Acad Soc Annu Meet 2015;1594:1707.

12 Vaucher YE, Peralta-Carcelen AM, Finer NN, Carlo W, Gantz MG, Walsh MC, Laptook AR, Yoder BA, Faix RG, Das A, Schibler K, Rich W, Newman NS, Vohr B, Yolton K, Heyne RJ, Wilson-Costello D, Evans PW, Goldstein RF, Acarregui MJ, Adams-Chapman I, Pappas A, Hintz SR, Poindexter B, Dusick AM, McGowan EC, Ehrenkranz RA, Bodnar A, Bauer CR, Fuller J, O'Shea TM, Myers GJ, Higgins RD, Support Study Group of the Eunice Kennedy Shriver NICHD Neonatal Research Network: Neurodevelopmental outcomes in the early CPAP and pulse oximetry trial. N Engl J Med 2012;367:2495-2504.

13 Barton SK, Tolcos M, Miller SL, Roehr CC, Schmölzer GM, Davis PG, Moss TJ, Hooper SB, Polglase GR: Unravelling the links between the initiation of ventilation and brain injury in preterm infants. Front Pediatr 2015; 3:97.

14 Barton SK, McDougall ARA, Melville JM, Moss TJ, Zahra VA, Lim T, Crossley KJ, Polglase G, Tolcos M: Differential short-term regional effects of early high dose erythropoietin on white matter in preterm lambs after mechanical ventilation. J Physiol 2016;594: 1437-1449.

15 Polglase GR, Hooper SB: Role of intra-luminal pressure in regulating $\mathrm{PBF}$ in the fetus and after birth. Curr Pediatr Rev 2006;2:287-299.
16 Skiold B, Wu Q, Hooper SB, Davis PG, McIntyre R, Tolcos M, Pearson J, Vreys R, Egan GF, Barton SK, Cheong JL, Polglase GR: Early detection of ventilation-induced brain injury using magnetic resonance spectroscopy and diffusion tensor imaging: an in vivo study in preterm lambs. PLoS One 2014;9:e95804.

17 Greisen G: Autoregulation of cerebral blood flow in newborn babies. Early Hum Dev 2005; 81:423-428.

18 Khwaja O, Volpe JJ: Pathogenesis of cerebral white matter injury of prematurity. Arch Dis Child Fetal Neonatal Ed 2008;93:F153-F161.

19 Roberts D, Dalziel S: Antenatal corticosteroids for accellerating fetal lung maturation for women at risk of preterm birth. Cochrane Database Syst Rev 2006, p CD00454.

20 Hillman NH, Pillow JJ, Ball MK, Polglase GR, Kallapur SG, Jobe AH: Antenatal and postnatal corticosteroid and resuscitation induced lung injury in preterm sheep. Respir Res 2009; 10:124.

21 Effect of corticosteroids for fetal maturation on perinatal outcomes. NIH Consens Statement 1994;12:1-24.

22 Crossley KJ, Morley CJ, Allison BJ, Davis PG, Polglase GR, Wallace MJ, Zahra VA, Hooper SB: Antenatal corticosteroids increase fetal, but not postnatal, pulmonary blood flow in sheep. Pediatr Res 2009;66:283-288.

23 Schwab M, Roedel M, Akhtar Anwar M, et al: Effects of betamethasone administration to the fetal sheep in late gestation on fetal cerebral blood flow. J Physiol 2000;528:619-632.

24 Wong D, Abdel-Latif M, Kent A: Antenatal steroid exposure and outcomes of very premature infants: a regional cohort study. Arch Dis Child Fetal Neonatal Ed 2014;99:F12F20.

25 Reiter RJ, Tan DX, Osuna C, Gitto E: Actions of melatonin in the reduction of oxidative stress. a review. J Biomed Sci 2000;7:444-458.

26 Reiter RJ, Tan DX: Melatonin: a novel protective agent against oxidative injury of the ischemic/reperfused heart. Cardiovasc Res 2003;58:10-19.

27 Tare M, Parkington HC, Wallace EM, Sutherland AE, Lim R, Yawno T, Coleman H, Jenkin G, Miller SL: Maternal melatonin administration mitigates coronary stiffness and endothelial dysfunction, and improves heart resilience to insult in growth restricted lambs. J Physiol 2014;592:2695-2709.

28 Herrera EA, Macchiavello R, Montt C, Ebensperger G, Diax M, Ramirez S, Parer JT, SeronFerre M, Reyes RV, Llanos AJ: Melatonin improves cerebrovascular function and decreases oxidative stress in chronically hypoxic lambs. J Pineal Res 2014;57:33-42.

29 Miller SL, Yawno T, Alers NO, Castillo-Melendez M, Supramaniam V, VanZyl N, Sabaretnam T, Loose J, Drummond GR, Walker DW, Jenkin G, Wallace EM: Antenatal antioxidant treatment with melatonin to decrease newborn neurodevelopmental deficits and brain injury caused by fetal growth restriction. J Pineal Res 2014;56:283-294.
30 Fulia F, Gitto E, Cuzzocrea S, Reiter RJ, Dugo L, Gitto P, Barberi S, Cordaro S, Barberi I: Increased levels of malondialdehyde and nitrite/ nitrate in the blood of asphyxiated newborns: reduction by melatonin. J Pineal Res 2001;31: 343-349.

31 Miller SL, Yan E, Castillo-Melendez M, Jenkin G, Walker DW: Melatonin provides neuroprotection in the late-gestation fetal sheep brain in response to umbilical cord occlusion. Dev Neurosci 2005;27:200-210.

32 Gitto E, Reiter RJ, Amodio A, Romeo C, Cuzzocrea E, Sabatino G, Buonocore G, Cardaro V, Trimarchi G, Barberi I: Early indicators of chronic lung disease in preterm infants with respiratory distress syndrome and their inhibition by melatonin. J Pineal Res 2004;36: 250-255.

33 Gitto E, Reiter RJ, Sebatino G, Buonocore G, Romeo C, Gitto P, Bugge C, Trimarchi G, Barberi I: Correlation among cytokines, bronchopulmonary dysplasia and modality of ventilation in preterm newborns: improvement with melatonin treatment. J Pineal Res 2005; 39:287-293.

34 Yawno T, Castillo-Melendez M, Jenkin G, Wallace EM, Walker DW, Miller SL: Mechanisms of melatonin-induced protection in the brain of late gestation fetal sheep in response to hypoxia. Dev Neurosci 2012;34: 543-551.

35 Rosenfeld WN, Davis JM: Prevention of oxygen radical disease in the newborn: possible therapeutic approaches. Semin Neonatol 1998;3:239-244.

36 Tataranno ML, Perrone S, Longini M, Buonocore G: New antioxidant drugs for neonatal brain injury. Oxid Med Cell Longev 2015; 2015:1-13.

37 Kaandorp J, Benders M, Schuit E, Rademaker C, Outijk M, Porath M, Oetomo SB, Wouters M, Elburg R, Franssen M, Bos A, de Haan T, Boon J, de Boer I, Rijnders R, Jacobs C, Scheepers L, Gavilanes D, Bloemenkamp K, Rijken M, Visser G, Mol BW, Van Bel F, Derks J: Maternal allopurinol administration during term labor for neuroprotection in case of fetal asphyxia: a multicenter randomized controlled trial. Am J Obstet Gynecol 2013; 208:S14.

38 Van Bel F, Shadid M, Moison RMW, Dorrepaal CA, Fontijn J, Monteiro L, Van De Bor M, Berger HM: Effect of allopurinol on postasphyxial free radical formation, cerebral hemodynamics, and electrical brain activity. Pediatrics 1998;101:185-193.

39 Veen S, De Haan MJJ, Martens SE, Rijken M, Van Bel F, Berger HM: Allopurinol (ALLO) treatment following severe asphyxia: followup at 2-years of age. Pediatr Res 1999;45: $230 \mathrm{~A}-230 \mathrm{~A}$.
Potential Therapies for

Ventilation-Induced Brain Injury
Neonatology 2016;110:155-162 DOI: $10.1159 / 000444918$ 
40 Kaandorp JJ, Benders MJNL, Schuit E, Rademaker CMA, Oudijk MA, Porath MM, Oetomo SB, Wouters MGAJ, van Elburg RM, Franssen MTM, Bos AF, de Haan TR, Boon J, de Boer IP, Rijnders RJP, Jacobs CJWFM, Scheepers LHCJ, Gavilanes DAW, Bloemenkamp KWM, Rijken M, van Meir CA, von Lindern JS, Huisjes AJM, Bakker SCMJER, Mol BWJ, Visser GHA, Van Bel F, Derks JB: Maternal allopurinol administration during suspected fetal hypoxia: a novel neuroprotective intervention? A multicentre randomised placebo controlled trial. Arch Dis Child Fetal Neonatal Ed 2015;100:F216-F223.

41 Russell GA, Cooke RW: Randomised controlled trial of allopurinol prophylaxis in very preterm infants. Arch Dis Child Fetal Neonatal Ed 1995;73:F27-F31.

42 Shah PS: Current perspectives on the prevention and management of chronic lung disease in preterm infants. Pediatr Drugs 2003;5:463480.

43 Van Der Kooij MA, Groenendaal F, Kavelaars A, Heijnen CJ, Van Bel F: Neuroprotective properties and mechanisms of erythropoietin in in vitro and in vivo experimental models for hypoxia/ischemia. Brain Res Rev 2008;59: 22-33.

44 Rees SM, Hale N, De Matteo R, Cardamone L, Tolcos M, Loeliger M, Mackintosh A, Shields A, Probyn ME, Greenwood D, Harding R: Erythropoietin is neuroprotective in a preterm ovine model of endotoxin-induced brain injury. J Neuropathol Exp Neurol 2010; 69:306-319.

45 Slusarski JD, McPherson RJ, Wallace GN, Juul SE: High-dose erythropoietin does not exacerbate retinopathy of prematurity in rats. Pediatr Res 2009;66:625-630.

46 Liu K, San T, Wang P, Liu YH, Zhang LW, Xue YX: Effects of erythropoietin on bloodbrain barrier tight junctions in ischemia-reperfusion rats. J Mol Neurosci 2013;49:369379.

47 Wu YW, Bauer LA, Ballard RA, Ferriero DM, Glidden DV, Mayock DE, Chang T, Durand DJ, Song D, Bonifacio SL, Gonzalez FF, Glass HC, Juul SE: Erythropoietin for neuroprotection in neonatal encephalopathy: safety and pharmacokinetics. Pediatrics 2012;130:683691.

48 Zhu C, Kang W, Xu F: Erythropoietin improved neurologic outcomes in newborns with hypoxic-ischemic encephalopathy. Pediatrics 2009;124:e218-e226.
49 Bierer R, Peceny C, Hartenberger CH, Ohls RK: Erythropoietin concentrations and neurodevelopmental outcomes in preterm infants. Pediatrics 2006;118:e635.

50 Neubauer AP, Voss W, Wachtendorf M, Jungmann T: Erythropoietin improves neurodevelopmental outcome of extremely preterm infants. Ann Neurol 2010;67:657-666.

51 Ohls RK, Ehrenkranz RA, Das A, Dusick AM, Yolton K, Romano E, Delaney-Black V, Papile LA, Simon NP, Steichen JJ, Lee KG: Neurodevelopmental outcome and growth at 18 to 22 months' corrected age in extremely low birth weight infants treated with early erythropoietin and iron. Pediatrics 2004;114:1287-1291.

52 Fauchere JC, Dame C, Vonthein R, Koller B, Arri S, Wolf M, Bucher HU: An approach to using recombinant erythropoietin for neuroprotection in very preterm infants. Pediatrics 2008; $122: 375$.

53 Leuchter RH, Gui L, Poncet A, Hagmann C, Lodygensky GA, Martin E, Koller B, Darqué A, Bucher HU, Hüppi PS: Association between early administration of high-dose erythropoietin in preterm infants and brain MRI abnormality at term-equivalent age. JAMA 2014;312:817-824.

54 Polglase G, Barton SK, Melville JM, Zahra VA, Wallace MJ, Siew ML, Tolcos M, Moss TJM: Prophylactic erythropoietin exacerbates ventilation-induced lung inflammation and injury in preterm lambs. J Physiol 2014;592: 1993-2002.

55 Vosdaganes P, Lim R, Moss TJ, Wallace EM: Cell therapy: a novel treatment approach for bronchopulmonary dysplasia. Pediatrics 2012;130:727-737.

56 Zhu D, Wallace EM, Lim R: Cell-based therapies for the preterm infant. Cytotherapy 2014; 16:1614-1628.

57 Sorsby A, Symons HM: Amniotic membrane grafts in caustic burns of the eye. Br J Ophthalmol 1946;30:337-345.

58 Faulk WP, Stevens PJ, Burgos H, Matthews R, Bennett JP, Hsi BL: Human amnion as an adjunct in wound healing. Lancet 1980:11561158 .

59 Ilancheran S, Michalska A, Peh G, Wallace EM, Pera M, Manuelpillai U: Stem cells derived from human fetal membranes display multilineage differentiation potential. Biol Reprod 2007;77:577-588.
60 Pera MF, Reubinoff B, Trounson A: Human embryonic stem cells. J Cell Sci 2000;113:510.

61 Murphy S, Rosli S, Acharya R, Mathias L, Lim R, Wallace E, Jenkin G: Amnion epithelial cell isolation and characterization for clinical use. Curr Protoc Stem Cell Biol 2010, DOI: 10.1002/9780470151808.sc01e06s13.

62 Bailo M, Soncini M, Vertua E, Signoroni PB, Sanzone S, Lombardi G, Arienti D, Calamani F, Zatti D, Paul P, Albertini A, Zorzi F, Cavagnini A, Candotti F, Wengler GS, Parolini O: Engraftment potential of human amnion and chorion cells derived from term placenta. Transplantation 2004;78:1439-1448.

63 Hodges RJ, Jenkin G, Hooper SB, Allison BJ, Lim R, Dickinson H, Miller SL, Vosdaganes P, Wallace EM: Human amnion epithelial cells reduce ventilation-induced preterm lung injury in fetal sheep. Am J Obstet Gynecol 2012; 206:448.e8-448.e15.

64 Vosdaganes P, Hodges RJ, Lim R, Westover AJ, Acharya R, Wallace EM, Moss TJM: Human amnion epithelial cells as a treatment for inflammation-induced fetal lung injury in sheep. Am J Obstet Gynecol 2011;205:156. e26-156.e33.

65 Zhu X, Wang X, Cao G, Liu F, Yang Y, Li X, Zhang Y, Mi Y, Liu J, Zhang L: Stem cell properties and neural differentiation of sheep amniotic epithelial cells. Neural Regen Res 2013; 8:1210-1219.

66 Kakishita K, Elwan MA, Nakao N, Itakura T, Sakuragawa N: Human amniotic epithelial cells produce dopamine and survive after implantation into the striatum of a rat model of Parkinson's disease: a potential source of donor for transplantation therapy. Exp Neurol 2000;165:27-34.

67 Sakuragawa N, Misawa H, Ohsugi K, Kakishita K, Ishii T, Thangavel R, Tohyama J, Elwan M, Yokoyama Y, Okuda O, Arai H, Ogino I, Sato K: Evidence for active acetylcholine metabolism in human amniotic epithelial cells: applicable to intracerebral allografting for neurologic disease. Neurosci Lett 1997;232: 53-56.

68 Yawno T, Schuilwerve J, Moss TJM, Vosdaganes P, Westover AJ, Afandi E, Jenkin G, Wallace EM, Miller SL: Human amnion epithelial cells reduce fetal brain injury in response to intrauterine inflammation. Dev Neurosci 2013;35:272-282. 